\title{
Spatial harvest scheduling for oak coppices conversion into high forest involving wood production management
}

\section{Programación espacial de cosecha para la conversión de bosques de encinas a monte alto que involucra el manejo de la producción de madera}

\author{
İnci Caglayan ${ }^{\text {a*}}$, Ahmet Yeşil b ${ }^{\text {, Hayati Zengin }}{ }^{\mathrm{c}}$, Murat Engin Ünal ${ }^{\mathrm{d}}$ \\ *Corresponding author: a Istanbul University-Cerrahpaşa, Faculty of Forestry, Department of Forest Management, \\ Istanbul, Turkey, phone: 05444005097.inciyaylaci@istanbul.edu.tr \\ ${ }^{\mathrm{b}}$ Istanbul University-Cerrahpaşa, Faculty of Forestry, Department of Forest Management, Istanbul, Turkey. \\ c Duzce University, Faculty of Forestry, Duzce, Turkey. \\ d Istanbul Technical University, Faculty of Management, Istanbul, Turkey.
}

\begin{abstract}
SUMMARY
Oak forests in northern Turkey have been largely managed as coppice. Nevertheless, in parallel with the decrease in demand of firewood and charcoal, the coppices, having no social demand or regional pressure, have been converted into high forests since 2006 . Because of this new regulation, a potential need has arisen to schedule forest harvests activities, which is based on the natural regeneration in those forests. The objective of this research was to develop a spatial forest planning process to schedule new harvests activities in coppices conversion into high forests. In the proposed study, four different planning strategies were used to estimate the most appropriate period for regeneration. Constraints essentially included those related to the need for an even flow, adjacency and to adhere to a maximum opening size. The scheduling process employed a mixed integer linear programming to schedule harvest activities and to maximize amount of harvested volume in planning horizon. The process was employed for the development of 100-year planning horizon for a Sergen forest range in the Thrace region of northern Turkey that was 3,448.8 ha in size. For obtaining various spatial data and solving the mathematical model, ArcMap and GAMS programs were used, respectively. Results showed that the value of the objective function in the case study forests could significantly increase when there is no constraint under the proposed harvesting plans in strategy $1\left(3,652,072.8 \mathrm{~m}^{3}\right)$. The amounts of wood production were similar in strategy $2\left(3,547,613.5 \mathrm{~m}^{3}\right)$ and strategy $4\left(3,547,393.5 \mathrm{~m}^{3}\right)$.
\end{abstract}

Key words: mixed integer programming, harvest scheduling, coppice forests, high forest.

\section{RESUMEN}

Los bosques de encina en el norte de Turquía se han manejado en gran medida como monte bajo. Pero, paralelamente a la disminución de la demanda de leña y carbón, los bosques sin demanda social o presión regional se han convertido en monte alto desde el año 2006. Debido a esta nueva regulación, ha surgido una necesidad potencial de programar actividades de aprovechamiento forestal, que se basa en la regeneración natural en esos bosques. El objetivo de esta investigación fue desarrollar un proceso de planificación espacial forestal para programar nuevas actividades de aprovechamiento en la conversión de bosques a montes altos. Se utilizaron cuatro estrategias de planificación para estimar el período más apropiado para la regeneración. Las restricciones esencialmente incluyen aquellas relacionadas con la necesidad de un flujo uniforme, adyacencia y de adherirse a un tamaño máximo de apertura. Se empleó programación lineal de enteros mixtos para programar actividades de cosecha y maximizar el volumen cosechado en el horizonte de planificación de 100 años para un rango de bosques de Sergen, región de Tracia, norte de Turquía (3.448,8 ha). Para obtener diversos datos espaciales y resolver el modelo matemático, se utilizaron los programas ArcMap y GAMS, respectivamente. Los resultados mostraron que el valor de la función objetivo en los bosques del estudio podría aumentar significativamente cuando no hay restricciones en los planes de aprovechamiento propuestos en la estrategia-1 $\left(3.652 .072,8 \mathrm{~m}^{3}\right)$. La producción de madera fue similar en la estrategia-2 $\left(3.547 .613,5 \mathrm{~m}^{3}\right)$ y la estrategia-4 $\left(3.547 .393,5 \mathrm{~m}^{3}\right)$.

Palabras clave: programación de enteros mixtos, programación de cosecha, bosques de monte bajo, monte alto.

\section{INTRODUCTION}

Operational Research (OR) techniques have been utilized in forest management since 1960s. In Turkey, these techniques have been used in forest management planning processes for more than 30 years. Among these techniques, optimization and simulation have been utilized for the solution of planning problems for many years in fo- 
restry organizations (Rönnqvist 2003, Kangas and Kangas 2005, Weintraub and Romero 2006). The reasons for the generality of operational research techniques in solving the forest planning problems can be exemplified with suitability, need for efficiency, scale, participation of OR experts, implementation strategy, improvement of PCs and software (Weintraub and Romero 2006). Among the operational research techniques, optimization models are the most commonly used to determine the optimal harvesting schedule in forest planning (Kaya et al. 2016). Among the types of optimization models, the most widely used are linear programming (LP) models, while mixed integer linear programming (MILP) models are also used as widely as LP methods (Nobre et al. 2016). These models for harvest scheduling are advantageous in situations such as dealing with objective functions and finding the appropriate solutions for complex constraints (Kangas and Kangas 2005, Weintraub and Romero 2006). Moreover, the number of studies dealing with optimization has increased because they make the complex structure of real systems more understandable, besides providing decision alternatives. The way of utilization of OR models for the forest management planning process was opened in the forest management regulation of 2008 because of the wide usage by many forestry organizations abroad and the progress obtained as a result of the studies in Turkey.

Harvest scheduling problems have two broad approaches that are the Area Restriction Model (ARM) (Murray and Snyder 2000) and Unit Restriction Model (URM) (Murray and Snyder 2000), which are commonly used in planning with adjacency constraints (Crowe et al. 2003, Borges et al. 2016). In URM, adjacent stands cannot be subject to final cutting in the same period; however, in ARM, adjacent stands are allowed in the same planning period as long as the total area of each final cutting area does not exceed the Maximum Open Area (MOA) (Crowe et al. 2003, Borges et al. 2016). Nevertheless, the ARM approach presents preferable objective function values contrasted with those of the URM, when it comes to spatial constraints related to final harvests (Murray et al. 2004). The size of MOA may also alternate according to countries. Other common restrictions for harvest scheduling are volume control (even-flow) and adjacency constraints.

Given the operational studies on forest planning, it can be seen that many problems have been handled and many models and solution proposals have been and are being developed (Kaya et al. 2016). Some previous examples of studies towards modern production planning are presented below.

Eraslan (1981), by introducing the Increment Percentages Simulation Method for achieving the optimal structure of even-aged forests, has explained the theoretical and practical principals. To give examples of harvest scheduling using mixed integer programming, Yoshimoto and Konoshima (2016) and Borges et al. (2016) utilized green-up constraint in optimization model. Vopenka et al.
(2015) utilized adjacency constraints, which are used in the decision support system called Optimal. Wei and Murray (2015) have tried to obtain the optimal solution by utilizing two multi-objective modeling approaches assessing spatial uncertainties and considering adjacency constraints. Ferreira et al. (2015) also maximized the forest value while addressing constraints as even-flow and wildfire resistance concerns. Könnyü and Tóth (2013) offered the algorithms for an integer programming problem in forest harvesting schedule. They scheduled spatial harvesting by employing binary decisions such as cutting or leaving the stands in different periods depending on spatial and temporal constraints. Also there are some examples on optimization of wood production in Turkey that mainly take into account the harvest scheduling in high forests (Başkent and Keles 2006, Keles et al. 2007).The above-mentioned studies have usually been carried out on high forest and plantation areas. However, these optimization studies have to be important for not only high forest or plantations area, which is one of the typical forest structures, but also for other coppices and coppices conversion into high forest.

The forests utilized in planned or unplanned way are divided into three classes by the regeneration method: high-forest, coppice, coppice with standards (Odabaş1 1976). Irregular harvestings made in high forests in order to meet the need for firewood and charcoal have shaped the coppices (Odabaş1 1976). In many of the studies, it has been reported that the coppices are not in harmony with nature, and that the productivity level of coppices are lower than that of high-forests and coppices with high-forest (Odabaş1 1976). This negativity has brought the studies on conversion into high-forest to prominence. Since the $1^{\text {st }}$ of January 2006, in parallel with the decreasing demand on wood and wood charcoal in Turkey, the decision has been made to convert the coppices and non-productive high forests, where there is no social demand and regional pressure, into high forests, regardless of the tree species. In parallel with this decision, according to the statistical data of General Directorate of Forestry for the year 2016, between 2005 and 2015, 3,025,935 ha of coppice area changed into high forest area for converting (GDF 2015). In Turkey, the coppices are operated via actual annual area method, while high forests are managed via age class method. However, as a result of conversion into high forest, these areas included in the high forest area should be operated via the age class method in the future. Because of this new regulation, the new necessity of scheduling harvests activities, which is based on the natural regeneration in those forests, has emerged. Since some uncertainties will be experienced in making the yield decisions in operating the areas, which are being converted via age class method, optimization techniques are recommended for the use during planning.

The objective of this research is to develop a spatial forest planning process to schedule new harvests activities in coppices conversion into high forests. Constraints essentially included those related to the need for an even 
flow, adjacency to restrict the opening of large areas along the regeneration process. Presently, the main objective of coppices conversion to high forest is to change from one regeneration system to another, nevertheless optimizing wood production, by utilizing intermediate and final yields after regeneration, is also required. Therefore, four different planning strategies were used to estimate the most appropriate period for regeneration. In all analyses, we utilized forest inventory data relating the entire Sergen forest range in the Thrace region of northern Turkey. The scheduling process employed a mixed integer linear programming to schedule harvests activities and to maximize the value of the objective function. The process was employed for the development of a 100-year planning horizon. For obtaining various spatial data and solving the mathematical model, ArcMap and GAMS programs were used, respectively.

\section{METHODS}

General characteristics of the study area. The study area is located in the Thrace region of northern Turkey $\left(41^{\circ} 40^{\prime}\right.$ $26^{\prime \prime}-41^{\circ} 46^{\prime} 46^{\prime \prime}$ North and $27^{\circ} 39^{\prime} 45^{\prime \prime}-27^{\circ} 50^{\prime} 21^{\prime \prime}$ East). The altitude of the planning unit varies between 250 $\mathrm{m}$ and $890 \mathrm{~m}$, while mean altitude is $480 \mathrm{~m}$ (figure 1). In the central Thrace region, where the planning unit is located, climate conditions are characterized as low precipitation, high temperature, low relative humidity and arid conditions. The annual mean temperature is $12.5^{\circ} \mathrm{C}$, and 30 -year mean precipitation of the region is $639.2 \mathrm{~mm}$ per year. On field, the limestones and Gnays-Metagranitoyit bedrocks are dominant. Soils contains trace amount of lime.

The most common tree species in the study area (approximately $85 \%$ ) is oak (Quercus spp.). Oak is a tree species ranging a wide area in Turkey and having 18 taxa. Three oak species of sessile oak (Quercus petraea (Mattuschka) Lieb. subsp. iberica (Steven ex Bieb) Krassilin, Hungarian oak (Quercus frainetto Ten.) and two sub-species of mossy oak (Quercus cerris L. var. cerris) and shallow lobed mossy oak (Quercus cerris L. var. austriaca (Willd) Loudon) are observed. Most stands consist of pure and even-aged oak stands (Eraslan and Evcimen 1967, Makineci et al. 2008). Another part of the stands consists of mixed oak stands containing oak as main species and beech (Fagus orientalis Lipsky), hornbeam (Carpinus betulus L.), alder (Alnus glutinosa (L.) Gaertn), ash tree (Fraxinus spp.) and maple (Acer spp.) as minority species.

The total area of the planning unit is 10,229.4 ha. However, in this study, the spatial harvest scheduling in oak coppices conversion into high forests comprised $3,448.8$ ha (figure 1). Although, 3,257 ha of this area is productive, and 191.8 ha is a non-productive forest area. From them, 2,959.6 ha (85.8 \%) are in site class III, and 297.4 ha $(8.6 \%)$ are in site class II. In the working circle of conversion into oak high forest, there were 87 com- partments and 210 stands (sub-compartments) and nine different pure and mixed oak stand types. From the aspect of areal distribution of stands, $86 \%$ of the stands are pure stands of oak, while other stands contain a mixture of other tree species. All of the stands in the study area were coppiced until the planning period of 2013. After 2013, in parallel with the decrease in demand of firewood and charcoal by regional population, these areas have also been planned as "working circle of conversion into oak high forest". The main function of the working circle of conversion into oak high forest is wood production.

Generating yield and adjacency matrixes. The main objectives in the oak working circle, namely the conversion into high forest and the maximization of wood production, was aimed, via the model, at revealing the amounts of final yield and thinning cut via the regeneration order of the stands and along the scope of planning.

One of the important points in studies of conversion into high forest is to determine the timing of regeneration. For regeneration timing, the year of seed abundancy is considered. Odabaşı (1976) has reported that the period between the ages of 50 and 60 is suitable for starting the natural regeneration for oak coppices. However, Makineci et al. (2008) have reported that leaflessness, indicating severe health problems, occurred in approximately $13 \%$ of the oak stands. As a result, considering that the maturity period may consist of several periods and health problems at oak stands, the lower limit of the maturity period was determined to be the age of 40 for site class II areas and the age of 60 for site class III areas.

In the optimization model, six possible prescriptions were created for five periods. For every scenario, some of the data used in each period should be prepared in matrix form. For this purpose, the matrices of growth rates, middiameter growth, thinning cut rates and adjacency were created. Other data are constant and they are not affected by the scenario selection.

In establishing the growth rate matrices, to determine the age-actual increment percentage relationship in site classes II and III, the increment percentages were calculated by using the data in the yield table (Eraslan and Evcimen 1967) in accordance with the method proposed by Eraslan (1981). Increment percentages are expressed in equations 9 and 12 of the optimization model. These equations are used in estimating the volume in the next period and in calculating the final yields of stands to be regenerated to ensure the balance between the periods in stands.

Mid-diameter growth of the stands was determined by using the yield table data. The ratio of actual growing stock of stand $\left(V_{a k t}\right)$ to the growing stock corresponding to the actual age of stand in yield table $\left(V_{o p t}\right)$ was considered to continue as is throughout the growth of stand. The mid-diameter development was calculated by multiplying the calculated ratio with the value in the yield table. The 


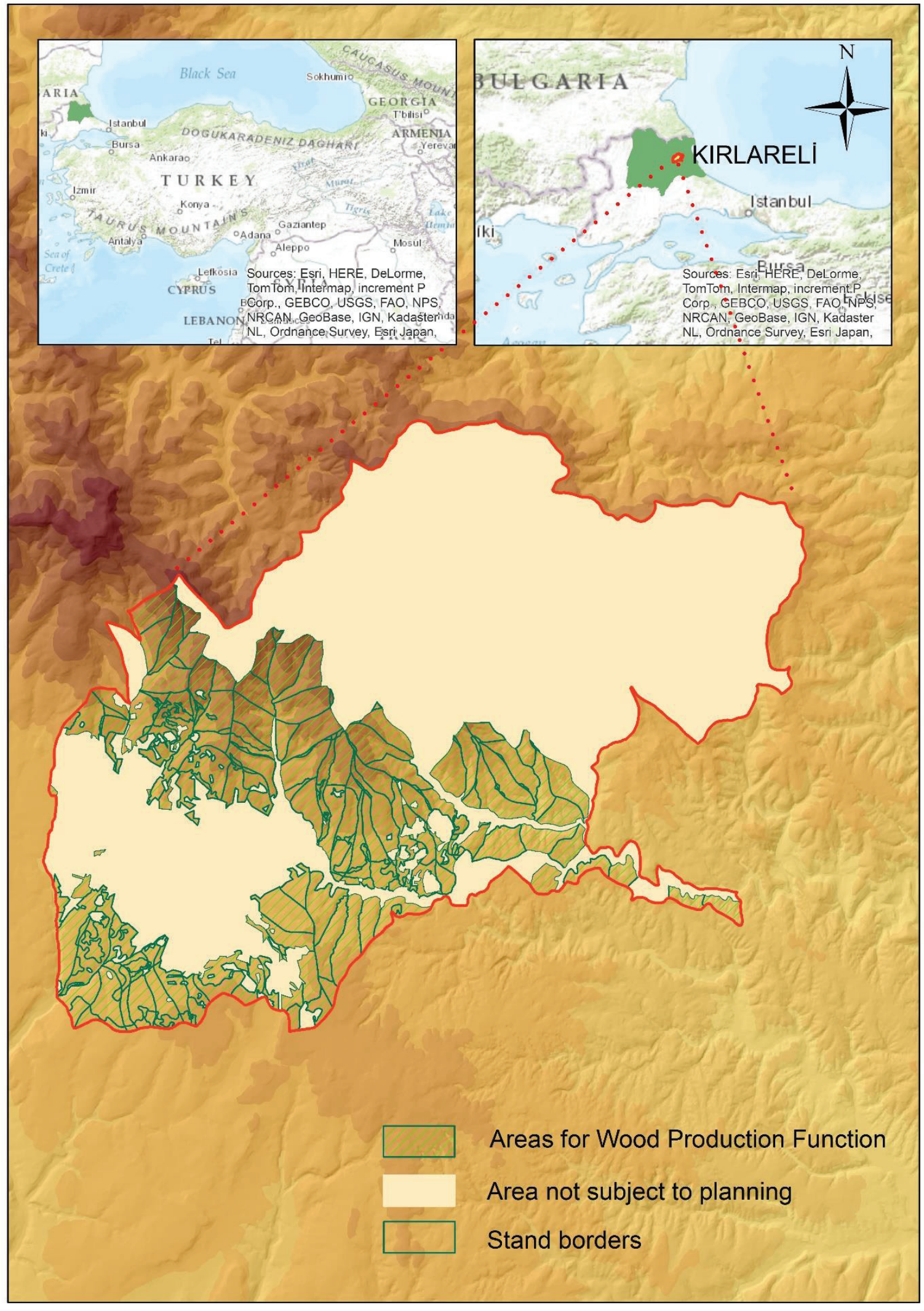

Figure 1. General characteristics of the study area.

Características generales del área de estudio. 
formula used in calculating the mid-diameter growth of stands is presented below.

$$
D t_{\text {value }}=\left(\frac{V_{a k t}}{V_{\text {opt }}}\right) \times D t_{\text {opt }}
$$

where, $D t_{\text {value }}$ is the mid-diameter value $(\mathrm{cm})$ for the age to be calculated, $D t_{\text {opt }}$ is the mid-diameter value $(\mathrm{cm})$ in the yield table corresponding to the age to be calculated.

For size II and III, the aim of calculating the mid-diameter growths of each stand type is to determine the development stages $(\mathrm{a}=$ young, $\mathrm{b}=$ pole stage, $\mathrm{c}=$ small wood, $\mathrm{d}=$ mature, $\mathrm{e}=$ over mature), because it was decided to determine the maximum and minimum cutting yields to be obtained from stands in accordance with developmental stages.

In areas of conversion into high forest, since the maintenance efforts are important for stand seed generation during advanced ages, the thinning cut to be achieved from the stands is also important. It was considered as appropriate to perform maintenance efforts in accordance with the stand developmental stages and to consider the thinning cut to be based on the stand volume, which is the common measurement unit. For this purpose, the lower and upper limits of the amount of thinning in accordance with the developmental stage of each stand is presented in table 1 (Zengin et al. 2015). The aim of determining the lower limit is to ensure the calculation of thinning cut for each stand and for every period except for the regeneration period.

By utilizing the stand mid-diameter matrices, the developmental stages were determined for various scenarios and every period. Afterward, in accordance with the stand developmental stages, the matrices of minimum and maximum thinning cut ratios were prepared.

It was decided to prevent simultaneous harvest of adjacent stands to avoid large openings in the forest canopy. The adjacent stands were determined in ArcMap software, and the adjacency relationships among stands were expressed with 0 and 1 integer decision variables. Adjacency relationships of the stands were introduced in equation 21. As an example, the adjacency matrices created for certain stands in working circle are presented in table 2.

Table 1. Minimum and maximum thinning cut ratios to be obtained from stands (Zengin et al. 2015).

Tasas mínimas y máximas de raleo que se obtendrán de los rodales (Zengin et al. 2015).

\begin{tabular}{lcccc}
\hline \multirow{2}{*}{ Developmental Stages } & \multicolumn{2}{c}{ Diameter class limits $(\mathrm{cm})$} & Symbol of Developmental Stage Nick & \multicolumn{2}{c}{ Ratio of thinning cut } \\
\cline { 3 - 5 } Young & $<8$ & $\mathrm{a}$ & Minimum \% & Maximum \% \\
Pole stage & $8-19.9$ & $\mathrm{~b}$ & 10 & 30 \\
Small wood & $20-35.9$ & $\mathrm{c}$ & 5 & 20 \\
Mature & $36-51.9$ & $\mathrm{~d}$ & 1 & 5 \\
Over mature & $52 \leq$ & $\mathrm{e}$ & & 5 \\
\hline
\end{tabular}

Table 2. Adjacency matrices of some of stands in working circle.

Matrices de adyacencia de algunos rodales en el área de trabajo.

\begin{tabular}{clcccccccccccc}
\hline \multirow{2}{*}{ Stand ID } & ID & 1 & 2 & 3 & 4 & 5 & 6 & 7 & 8 & 9 & 10 \\
\cline { 2 - 5 } & Stand types & Ma3 & Ma3 & Ma3 & MKnDya3 & Ma3 & Ma3 & Mab3 & Mab2 & Mab3 & BM \\
\hline 1 & Ma3 & 1 & 0 & 0 & 0 & 0 & 0 & 0 & 0 & 0 & 0 \\
2 & Ma3 & 0 & 1 & 1 & 0 & 1 & 0 & 0 & 0 & 0 & 0 \\
3 & Ma3 & 0 & 1 & 1 & 1 & 1 & 1 & 1 & 0 & 0 & 0 & 0 & 0 \\
4 & MKnDya3 & 0 & 0 & 1 & 1 & 0 & 0 & 1 & 0 & 0 & 0 \\
5 & Ma3 & 0 & 1 & 1 & 0 & 1 & 0 & 0 & 0 & 0 & 0 \\
6 & Ma3 & 0 & 0 & 1 & 0 & 0 & 1 & 1 & 0 & 0 & 0 \\
7 & Mab3 & 0 & 0 & 1 & 1 & 0 & 1 & 1 & 0 & 1 & 0 \\
8 & Mab2 & 0 & 0 & 0 & 0 & 0 & 0 & 0 & 1 & 1 & 1 \\
9 & Mab3 & 0 & 0 & 0 & 0 & 0 & 0 & 1 & 1 & 1 & 1 \\
10 & BM & 0 & 0 & 0 & 0 & 0 & 0 & 0 & 1 & 1 & 1 \\
\hline
\end{tabular}


Non-productive stands, which are not eligible for natural regeneration, were determined according to the actual increment percentages at the middle age of each period regarding the various age classes in accordance with the mean site class (site class III), and it was assumed that they will grow in this parallel after forestation. Since no age class and site class classifications were executed in the management plan for non-productive stands, it was assumed that there was no growing stock in those areas, and their mid-diameter growth matrices were created by utilizing the yield table according to the mean site class.

Establishing the optimization model. If some decision variables take real number values and some take integer values, the "mixed interrupted optimization" problem is observed (Taha 2006). In interrupted optimization problems, if any of the decision variables takes any integer value, then the integer programming is utilized (Taha 2006). In this problem, the constraints containing the selection of various scenarios and adjacency relationships towards the spatial planning necessitated the formulation of the problem with Mixed Integer Programming, and a model optimizing the production was designed by using this technique.

The forest plans developed cover a 100-year planning horizon that is divided into five 20 -year planning periods, and it was assumed that the stands that will reach regeneration maturity in the period estimated by the model will be regenerated naturally. The volume growth of existing stands was determined according to the "Increment Percentage Simulation Method" developed by Eraslan (1981). As the management method, the age class method was used, and periodic final yield was determined according to this method. In Turkey, yield tables are prepared for pure and even-aged stands. For this reason, for mixed stands, the main tree species (oak) is considered while calculating the volume of tim- ber. For this purpose, the oak yield table (Eraslan and Evcimen 1967) was used for pure stands. Stand volumes were calculated as mid-period values. For non-productive stands, it was assumed that there was no growing stock in those areas (however, there may be some little growing stock on non-productive areas) to prepare the matrices for these areas easily. Their mid-diameter growth matrices were created by utilizing the oak yield table according to the mean site class. In stands to be regenerated, the regeneration operation can be performed in any planning period within the "maturity period" (consisting of several planning periods), lower limit of which varies depending on the site class. Depending on their developmental stages, a certain portion of their volume has been taken from stands to be maintained as thinning cut. The borders are assumed to be unchanged during the planning horizon. The candidates for regeneration were considered to be after the age of 40 for oaks in good sites (site class II zones) and after the age of 60 for those in other sites (site class III zones). In order to prevent the model from performing regeneration on very large areas at the same time, the maximum open area was limited by adjacency constraints. Instead of giving a certain area, it is not allowed to harvest more than 3 neighbor stands for strategies 2 and 4 at the same period. The Optimal Periodical Area (OPA) that limits the total regeneration area in 20 year periods was used as 1,000 hectares in the planning model.

From these assumptions, by using the mathematical models developed to determine wood production based on stand volume, an original optimization model was designed for the oak (conversion to high forest) working circle constituting the study area. The basic decision variable in the model is the volumes to be taken from stands via both final cutting and thinning. The mathematical equation of mixed integer programming, the objective function, the constraints and other components are as follows.

$$
Z_{\text {max }}=\sum_{d} P V_{d}=P V_{1}+P V_{2}+P V_{3}+P V_{4}+P V_{5}
$$

Subject to:

$$
\begin{array}{ll}
T R_{d}=\sum_{k} \sum_{i} G_{k, i, d} & (d=1, \ldots 5) \\
T M_{d}=\sum_{k} \sum_{i} X_{k, i, d} & (d=1, \ldots 5) \\
P V_{d}=T R_{d}+T M_{d} & (d=1, \ldots 5) \\
V_{k, i, p_{1}}=A V_{k} \times y_{k, i} \times A_{k} & \forall k, i \\
X_{k, i, p_{6}}=0 & \forall k, i \\
G_{k, i, p_{6}}=0 & \forall k, i
\end{array}
$$




$$
\begin{array}{lc}
\left(1+n \times G R_{k, i, j}\right) \times V_{k, i, j}-X_{k, i, j}=V_{k, i, j+1} & (k, i, j) \epsilon\{(k, i, j) ; i \neq j, j<6\} \\
V_{k, i, j}=10 V_{k, i, j} \times y_{k, i} \times A_{k} & (k, i, j) \epsilon\{(k, i, j) ; i=j-1, j<6\} \\
G_{k, i, d}=0 & (k, i, d) \epsilon[(k, i, d) ; i \neq d\} \\
G_{k, i, d}=V_{k, i, d}+n \times \frac{G R_{k, i, d} x V_{k, i, d}}{2} & (k, i, d) \epsilon\{(k, i, d) ; i=d, d<6\} \\
X_{k, i, d}=0 & (k, i, d) \epsilon\{(k, i, d) ; i=d\} \\
k m_{i n} n_{k, i, d} \times V_{k, i, d} \leq X_{k, i, d} & (k, i, d) \epsilon\{(k, i, d) ; i \neq d, d<6\} \\
k m a x_{k, i, d} \times V_{k, i, d} \geq X_{k, i, d} & (k, i, d) \epsilon\{(k, i, d) ; i \neq d\} \\
1+r W o o d \times P V_{d} \geq P V_{d+1} & (d) \epsilon\{(d) ; d<5\} \\
1-r W o o d \times P V_{d} \leq P V_{d+1} & (d) \epsilon\{(d) ; d<5\} \\
\sum_{i} y_{k, i}=1 & (k=1, \ldots 210) \\
y_{k, i}=0 & (k, i) \epsilon\left\{(k, i) ; i<F P R_{k}\right\} \\
\sum_{k} y_{k, i} \times A_{k} \leq O P A & \\
\sum_{k j} \text { adjacency }{ }_{k i, k j} \times y_{k j, i} \leq \text { Maxadjacency } & \forall k i, i
\end{array}
$$

Coefficients:

rWood: the allowed change ratio of wood between the periods (wood flow) (\%).

$n$ : Period length (20 years).

OPA: Optimal Periodical Area (ha) to limit the total area of regenerated stands at any period.

Maxadjacency: maximum number of adjacent stands allowed for regeneration in the same period.

Basic variables:

$X_{k, i, d}:$ the amount of wood to be taken from $\mathrm{k}^{\text {th }}$ stand in $\mathrm{d}^{\text {th }}$ period according to $\mathrm{i}^{\text {th }}$ scenario $\left(\mathrm{m}^{3}\right)$.

$Y_{k, i}$ : the binary variable indicating if the $\mathrm{i}^{\text {th }}$ scenario will be chosen for $\mathrm{k}^{\text {th }}$ stand or not $(0-1)$

Calculation variables:

$Z$ : value of objective function (total yield).

$V_{k, i, d}:$ the volume $\mathrm{k}^{\text {th }}$ stand at the beginning of $\mathrm{d}^{\text {th }}$ period according to $\mathrm{i}^{\text {th }}$ scenario $\left(\mathrm{m}^{3}\right)$.

$T R_{d}$ : the final yield to be taken in $\mathrm{d}^{\text {th }}$ period as a result of regeneration of stands $\left(\mathrm{m}^{3}\right)$.

$T M_{d}$ : the thinning cut to be taken in $\mathrm{d}^{\text {th }}$ period $\left(\mathrm{m}^{3}\right)$.

$P V_{d}$ : Total amount of all the wood to be taken in $\mathrm{d}^{\text {th }}$ period $\left(\mathrm{m}^{3}\right)$.

$G_{k, i d}:$ the periodic final yield to be obtained from $\mathrm{k}^{\text {th }}$ stand's regeneration in $\mathrm{d}^{\text {th }}$ period according to $\mathrm{i}^{\text {th }}$ scenario $\left(\mathrm{m}^{3}\right)$. $X_{k, i, d}$ : the thinning cut to be taken from $\mathrm{k}^{\text {th }}$ stand in $\mathrm{d}^{\text {th }}$ pe$\operatorname{riod}\left(\mathrm{m}^{3}\right)$.

Other terms:

$V_{k, i, p}:$ the volume $\mathrm{k}^{\text {th }}$ stand at the beginning of period according to $\mathrm{i}^{\text {th }}$ scenario $\left(\mathrm{m}^{3}\right)$.

$X_{k, i, p}$ : the thinning cut to be obtained from $\mathrm{k}^{\text {th }}$ stand's regeneration in period ( $6^{\text {th }}$ period) according to $i^{\text {th }}$ scenario $\left(\mathrm{m}^{3}\right)$.

$G_{k, i, p 6}:$ the final yield to be obtained from $\mathrm{k}^{\text {th }}$ stand's regeneration in period $\left(6^{\text {th }}\right.$ period $)$ according to $\mathrm{i}^{\text {th }}$ scenario $\left(\mathrm{m}^{3}\right)$.

$V_{k, i j}$ : the volume of $\mathrm{k}^{\text {th }}$ stand at the beginning of $\mathrm{j}^{\text {th }}$ period according to $\mathrm{i}^{\text {th }}$ scenario $\left(\mathrm{m}^{3}\right)$.

$X_{k, i j}$ : the amount of thinning cut to be obtained from $\mathrm{k}^{\text {th }}$ stand in $\mathrm{d}^{\text {th }}$ period according to $\mathrm{i}^{\text {th }}$ scenario $\left(\mathrm{m}^{3}\right)$.

$10 x V_{k, i, j}$ : the volume of $\mathrm{k}^{\text {th }}$ stand at $10^{\text {th }}$ age (after being regenerated) $\left(\mathrm{m}^{3}\right)$.

$A V_{k}$ : actual volume of $\mathrm{k}^{\text {th }}$ stand $\left(\mathrm{m}^{3}\right)$.

$A_{k}:$ area of $\mathrm{k}^{\text {th }}$ stand (ha).

$G R_{k, i, j}$ : increament in volume of $\mathrm{k}^{\text {th }}$ stand in $\mathrm{j}^{\text {th }}$ period according to $i^{\text {th }}$ scenario (Growth Rate).

$\operatorname{kmin}_{k, i, d}, \operatorname{kmax}_{k, i, d}:$ maximum and minimum levels of thinning cut to be obtained from $\mathrm{k}^{\text {th }}$ stand in $\mathrm{d}^{\text {th }}$ period. 
adjacency $_{k i, k j}$ : the adjacency situation of $\mathrm{k}^{\text {th }}$ stand and $\mathrm{c}^{\text {th }}$ stand (0-1).

$c$ : the cluster of stands that may be adjacent to $\mathrm{k}^{\text {th }}$ stand.

$k$ : the stands allocated to regeneration $(\mathrm{k}=1 \ldots 210)$.

$F P R_{k}$ : the first period in which the stands to be regenerated can be regenerated $(1 \ldots . .210)$.

$i$ : the number of scenario $(\mathrm{i}=1 \ldots . .6)$.

$j$ : the number of period $(\mathrm{j}=1 \ldots .6)$.

$d$ : the sub-cluster of the number of period $(\mathrm{d}=1 \ldots .5)$.

Objective function (equation 2) represents maximizing the total wood production throughout the planning horizon. Equation 3 represents the sum of periodic final yield. It is required to obtain thinning cut from each stand that has been left for regeneration at least once throughout the planning horizon. Equation 4 represents the sum of thinning cuts to be obtained from any period. Equation 5 provides the sum of woods. In equation 6 , by selecting any of the scenarios, it is aimed at increasing the stands in proportion to their actual volumes. In equations 7 and 8 , the model is prevented from calculating any intermediate or final yield for the last $\left(6^{\text {th }}\right)$ period. Equation 9 represents the performance of volume growth of stands until the period in which they will be regenerated, in accordance with the increment percentage simulation method. Equation 10 represents the volume developments of every stand in periods after regeneration. Equation 11 ensures that no final yield is calculated except for the period in which the stands will be regenerated. Equation 12 allows us to calculate the final yield. Equation 13 ensures that no thinning cut would be harvested from the stands to be regenerated within the same period of final yield. Equations 14 and 15 are used to prevent the thinning cut amount to be taken from stands from exceeding the determined level (even-flow constraint). Equations 16 and 17 control the wood flow among the periodic total woods. For any of the stands, the stand growth can be continued in accordance only with one of the scenarios. The selection of the most appropriate scenario is made via equation 18. Equation 19 was added to prevent the inclusion of stands into regeneration before the management time determined according to the site class. Equation 20 was added to prevent the model from making regeneration in very large areas in a period. It ensures the performance of regeneration at the level of largest OPA size. Equation 21 was added to consider the adjacency relationships of the stands and to ensure the regeneration of a few (3) neighbor stands in the same period.

Planning strategies. For the strategies, to ensure the regular course of total wood amount consisting of the sum of periodic intermediate and final yields and adjacency constraint to limit the areas to be regenerated in a period from an entire working circle, the periodic wood flow constraints were added. The upper limit for periodic wood flow in the model for strategy 4 is not given. In other words, Strategy 4 was developed without the equation 16 . Through these two set of constraints, four different strategies were developed (table 3).

Table 3. Planning strategies.

Estrategias de planificación.

\begin{tabular}{|c|c|c|c|}
\hline Strategy number & Constraint & Objective & Level \\
\hline 1 & $\begin{array}{l}\text { a) Periodic wood flow shall not be } \\
\text { considered. } \\
\text { b) Adjacency constraint shall not } \\
\text { be considered. }\end{array}$ & $\begin{array}{l}\text { The maximization of wood } \\
\text { production when there is no } \\
\text { constraint }\end{array}$ & $\begin{array}{l}\text { a) } r \text { Wood } \geq 0 \\
\text { b) maxadjacency } \geq 1\end{array}$ \\
\hline 2 & $\begin{array}{l}\text { a) Periodic wood flow shall not be } \\
\text { considered. } \\
\text { b) Adjacency constraint shall be } \\
\text { considered. }\end{array}$ & $\begin{array}{l}\text { Maximization of wood production } \\
\text { in case of regeneration of three } \\
\text { adjacent stands at most }\end{array}$ & $\begin{array}{l}\text { a) } r \text { Wood } \geq 0 \\
\text { b) } \text { maxadjacency } \leq 3\end{array}$ \\
\hline 3 & $\begin{array}{l}\text { a) Periodic wood flow shall be } \\
\text { controlled. } \\
\text { b) Adjacency constraint shall not } \\
\text { be considered. }\end{array}$ & $\begin{array}{l}\text { Maximization of wood production } \\
\text { in case of } 120 \% \text { of periodic wood } \\
\text { flow rate }\end{array}$ & $\begin{array}{l}\text { a) } r \text { Wood }=1.20 \\
\text { b) } \text { maxadjacency } \geq 1\end{array}$ \\
\hline 4 & $\begin{array}{l}\text { a) Periodic wood flow shall be } \\
\text { considered for lower limit. } \\
\text { b) Adjacency constraint shall be } \\
\text { considered. }\end{array}$ & $\begin{array}{l}\text { Maximization of wood production } \\
\text { in case of } 10 \% \text { of periodic wood } \\
\text { flow rate and regeneration of three } \\
\text { adjacent stands at most }\end{array}$ & $\begin{array}{l}\text { a) } r \text { Wood }=0.10 \\
\text { b) maxadjacency } \leq 3\end{array}$ \\
\hline
\end{tabular}




\section{RESULTS}

Strategy 1 was aimed at maximizing the total wood production to be obtained from a working circle at the end of the planning horizon when there is no constraint. Since it was specified that the growing stock in non-productive areas should be removed at the first period, the final yield was taken from 191.8 ha area in the first period (P1) (figure 2).

In strategy 2 the adjacency constraint allowing the regeneration of three or less $t$ stands in the same period was added, and the periodic wood flow was not considered. In the model, it was specified that the entire non-productive areas (191.8 ha) should be regenerated in the first period, however since the adjacency constraint was added, final yield was taken from 176.1 ha of area in the first period (figure 2).

In strategy 3 , the adjacency constraint was not considered, and the periodic wood flow constraint preventing the fluctuation between the amounts of wood production obtained via final cutting and thinning in every period from exceeding over $120 \%$ was added. As a result of the trials made after adding only the wood flow constraint in the model, no suitable solution could be found for values lower than $120 \%$, nonetheless suitable solutions could be found when higher values were used. In the first period (P1), final yield was obtained from entire 191.8 ha nonproductive areas (figure 2).

In strategy 4, the adjacency constraint allowing the regeneration of three or less adjacent stands in the same period was added. Moreover, the periodic wood flow constraint preventing the $>10 \%$ fluctuation between the wood production obtained via both final cutting and thinning in every period was added. The necessity of regeneration of entire non-productive areas (191.8 ha) was specified although, since the adjacency constraint was added, final yield could be obtained from only 176.1 ha in the first period (figure 2).

At the end of planning horizons, a total of 3,745,081.9 $\mathrm{m}^{3}$ in strategy $1,3,641,075.3 \mathrm{~m}^{3}$ in strategy $2,1,457,997.0$ $\mathrm{m}^{3}$ in strategy $3,3,641,445.4 \mathrm{~m}^{3}$ in strategy 4 wood production was scheduled (figure 3), and $98 \%$ in strategy 1 , $97 \%$ in strategy 2, $91 \%$ in strategy 3, $97 \%$ in strategy 4 , of this amount was final yield (table 4), and $2 \%$ in strategy $1,3 \%$ in strategy $2,9 \%$ in strategy $3,3 \%$ in strategy 4 was thinning cut (table 5).

According to the findings regarding the variation of the areas to obtain final yield in various periods from the aspect of strategies (figure 2), the sizes of regeneration areas in the first two periods were very close to each other for strategy 1, strategy 2, strategy 3 and strategy 4 , and they constantly increased until the $3^{\text {rd }}$ period. Starting from the $3^{\text {rd }}$ period to the end of planning horizon, strategy 1 , strategy 2 and strategy 4 regenerated an area up to the top level of the maximum open area constraint (1,000 ha) implemented in almost all the strategies. Although, as a result of the decrease in options after adding the adjacency and wood flow constraints in strategy 3 , the regeneration could be performed on a smaller area in proportion to other strategies. Especially in the last period, the area to be regenerated was larger than in other periods. The reason for this is the maximization of wood production.

According to the findings regarding the variation of thinning cut amount among strategies, the courses of thinning cut amounts overlap each other for the first period for strategy 1 , strategy 2 and strategy 4 , nonetheless the highest level of thinning cut was obtained from strategy 3 (table 5). In all the strategies, the highest level of thinning cut was obtained in second period. However, the highest level of thinning cut in the second period was obtained

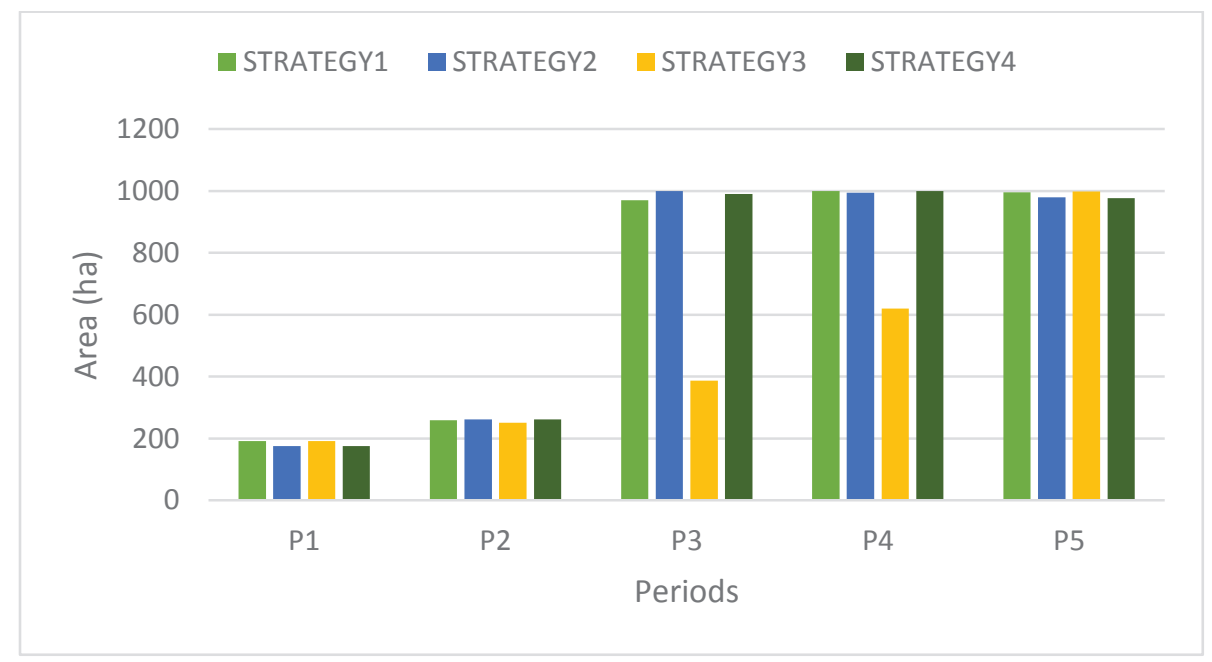

Figure 2. The distribution of areas to be regenerated in every period by the strategies.

Distribución de las áreas a regenerar en cada período por las estrategias. 
from strategy 3 in proportion to other periods. The thinning cut gradually decreases after the $2^{\text {nd }}$ period. The level of thinning cut to be obtained from strategy 3 is higher than those from all other strategies (table 5).

According to the findings related with the variation of total wood production amounts in various periods from the aspect of strategies, it can be seen that wood production was low in the first period for all the strategies but gradually increased in further periods. The development of total wood production was similar in strategy 2 and strategy 4 (figure 3). In these two strategies, the amounts of wood production are $22,326.2 \mathrm{~m}^{3}$ and $22,375.9 \mathrm{~m}^{3}$. In strategy 1, where the highest level of wood production could be achieved, the level of wood production in the $4^{\text {th }}$ period was lower than in strategy 2 and strategy 4 but higher than in strategy 3 (figure 3). The highest level of wood production was obtained from strategy 1 in the $5^{\text {th }}$ period, while the lowest level was obtained from strategy 3 . As in all other periods, the levels of wood productions in strategy 4 and strategy 2 are close to each other. It can be seen in all the

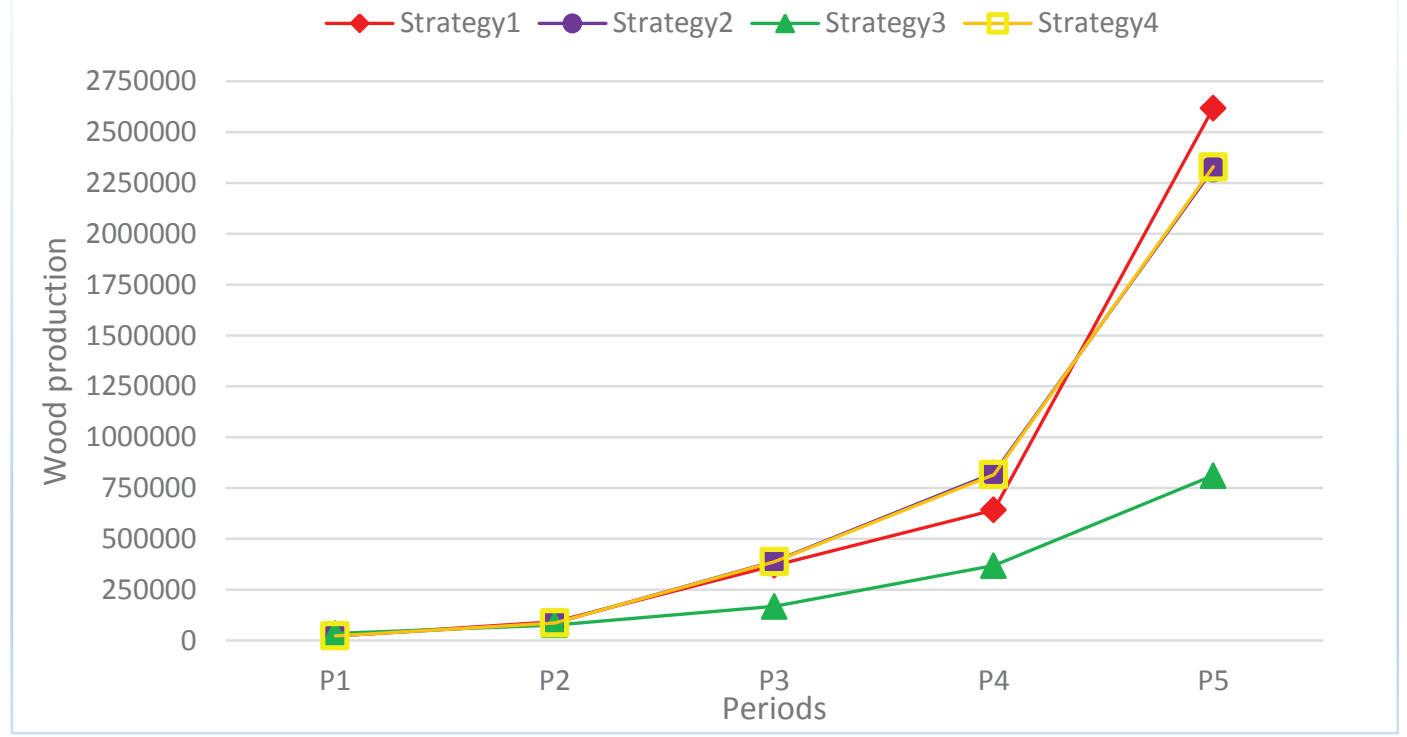

Figure 3. The periodic total wood production amounts by the different strategies.

Las cantidades de producción de madera periódicas totales por las diferentes estrategias.

Table 4. The amount of periodic final yield by various strategies.

Cantidad de rendimiento periódico final según varias estrategias.

\begin{tabular}{lcccccccc}
\hline & \multicolumn{2}{c}{ Strategy 1 } & \multicolumn{2}{c}{ Strategy 2 } & \multicolumn{2}{c}{ Strategy 3 } & \multicolumn{2}{c}{ Strategy 4 } \\
\cline { 2 - 8 } $\begin{array}{l}\text { Period } \\
\text { number }\end{array}$ & $\begin{array}{c}\text { Final } \\
\text { yield(FY) }\end{array}$ & $\%(\mathrm{FY})$ & $\begin{array}{c}\text { Final } \\
\text { yield(FY) }\end{array}$ & $\%(\mathrm{FY})$ & $\begin{array}{c}\text { Final } \\
\text { yield(FY) }\end{array}$ & $\%(\mathrm{FY})$ & $\begin{array}{c}\text { Final } \\
\text { yield(FY) }\end{array}$ & $\%(\mathrm{FY})$ \\
\cline { 2 - 9 } & \multicolumn{1}{c}{$\mathrm{m}^{3}$} & $\%$ & $\mathrm{~m}^{3}$ & $\%$ & $\mathrm{~m}^{3}$ & $\%$ & $\mathrm{~m}^{3}$ & $\%$ \\
\hline P1 & $3,997.5$ & 18 & $3,673.8$ & 16 & $3,997.5$ & 12 & $3,682.2$ & 16 \\
P2 & $62,875.4$ & 68 & $56,969.7$ & 66 & 43359.7 & 57 & $56,961.3$ & 66 \\
P3 & $348,860.0$ & 94 & $369,170.0$ & 95 & $138,210.0$ & 82 & $366,830.0$ & 95 \\
P4 & $628,440.0$ & 98 & $809,700.0$ & 98 & $349,220.0$ & 95 & $801,920.0$ & 98 \\
P5 & $2,607,900.0$ & 99 & $2,308,100.0$ & 99 & $797,320.0$ & 98 & $2,318,000.0$ & 99 \\
Total & $3,652,072.8$ & 98 & $3,547,613.5$ & 97 & $1,332,107.1$ & 91 & $3,547,393.5$ & 97 \\
\hline
\end{tabular}


Table 5. The amount of periodic thinning cut by various strategies.

Cantidad de rendimiento periódico por raleo según varias estrategias.

\begin{tabular}{|c|c|c|c|c|c|c|c|c|}
\hline \multirow{3}{*}{$\begin{array}{l}\text { Period } \\
\text { number }\end{array}$} & \multicolumn{2}{|c|}{ Strategy 1} & \multicolumn{2}{|c|}{ Strategy 2} & \multicolumn{2}{|c|}{ Strategy 3} & \multicolumn{2}{|c|}{ Strategy 4} \\
\hline & $\begin{array}{l}\text { Thinning cut } \\
\text { (IY) }\end{array}$ & $\%(\mathrm{IY})$ & $\begin{array}{l}\text { Thinning cut } \\
\text { (IY) }\end{array}$ & $\%(\mathrm{IY})$ & $\begin{array}{l}\text { Thinning cut } \\
\text { (IY) }\end{array}$ & $\%(\mathrm{IY})$ & $\begin{array}{l}\text { Intermediate } \\
\text { yield (IY) }\end{array}$ & $\%(\mathrm{IY})$ \\
\hline & $\mathrm{m}^{3}$ & $\%$ & $\mathrm{~m}^{3}$ & $\%$ & $\mathrm{~m}^{3}$ & $\%$ & $\mathrm{~m}^{3}$ & $\%$ \\
\hline P1 & $18,638.9$ & 82 & $18,652.5$ & 84 & $30,623.2$ & 88 & $18,693.7$ & 84 \\
\hline P2 & $29,506.1$ & 32 & $29,710.2$ & 34 & $32,805.7$ & 43 & $29,778.3$ & 34 \\
\hline P3 & $20,308.7$ & 6 & $20,259.2$ & 5 & $29,352.2$ & 18 & $20,501.1$ & 5 \\
\hline P4 & $13,594.1$ & 2 & $13,705.2$ & 2 & $19,419.0$ & 5 & $13,818.0$ & 2 \\
\hline P5 & $10,961.3$ & 1 & $11,134.9$ & 1 & $13,689.8$ & 2 & $11,260.8$ & 1 \\
\hline Total & $93,009.1$ & 2 & $93,461.8$ & 3 & $125,889.9$ & 9 & $94,051.9$ & 3 \\
\hline
\end{tabular}

strategies that the level of wood production periodically increased. At the same time, the portion of final yield to be obtained via final cutting was gradually increasing since the $1^{\text {st }}$ period, while a decrease was observed in thinning cut amounts in the last four periods.

The spatial distributions of 100-year cuttings for alternative strategy options are presented in figure 4 . Regeneration periods denote $1,2,3,4,5$ and maintenance cutting intensities which represent the $1 \%, 5 \%, 10 \%, 20 \%$ and $30 \%$ denote 0 , respectively; another area denotes nonforest land and coppices.

\section{DISCUSSION}

The optimization studies on wood production in forestry are generally carried out by using the maximization of the net present value (Borges et al. 2016, Nakajima et al. 2016) or minimization of costs. However, in this study like similar studies in Turkey (Başkent and Keles 2006, Keles et al. 2007), it was aimed at maximizing the objective function by considering wood production amount $\left(\mathrm{m}^{3}\right)$ rather than wood production value.

To determine the mean increment percentages in the middle age of the period for site classes II and III arranged for even-aged oak stands, the yield table developed by Eraslan and Evcimen (1967) via graphic method was utilized. In this study, to involve the gradually decreasing effect, stand volumes were calculated according to the middle age of the period. To determine the $5^{\text {th }}$ period volume values in accordance with the increment percentages simulation method, it is required to know the volumes transferred to the $6^{\text {th }}$ period. For this reason, the matrices were prepared also for the $6^{\text {th }}$ period. For this purpose, equations 7 and 8 prevented the calculation of any intermediate and final yield for the final period $\left(6^{\text {th }}\right.$ period $)$.
Considering the prepared planning strategies, it is seen that the highest level of wood production was achieved with strategy 1 . Since, except for the constraint of maximum open area limit at 1,000 ha for periods, the constraints of periodic wood flow and number of adjacent stands to be regenerated in a single period were loosened, the decision alternatives of the model increased, and the highest level of wood production was achieved via ordering and selecting the most appropriate alternatives. Since the number of alternatives would decrease when constraints were added, it caused the decrease in total benefit. The periodic course of total wood production for strategy 2 and strategy 4 were almost overlapping. The difference occurred in the maintenance woods and the stands selected for regeneration. The main reason of that is thought to be the adjacency constraint. The periodic wood flow constraint added in strategy 4 has not affected the general trend. Since only the periodic wood flow was added in strategy 3 , it was aimed at performing minimal cutting according to other strategies. As a result, it provides the lowest level of final yield. For all the strategies, almost $90 \%$ of the wood was obtained as final yield. The reason for this is the regeneration requirement of stands reached at maturity.

Considering all planning strategies, it is seen that more wood production is obtained by increasing the size of the harvest area (figure 2). Nalle et al. (2005) and Borges et al. (2016) have confirmed that the economic gainfulness of an optimal forest management plan typically increased with the size of the harvest area.

Considering age distribution, no stand reached or was reaching maturity (regeneration maturity), because most of the stands in the working circle were in Age I group. Since the sufficient seed generation level expected from the working circle cannot be reached in regeneration of stands before maturity period, the lower age limit was defined for the first period for regeneration of stands. Moreover, since 
Strategy 1

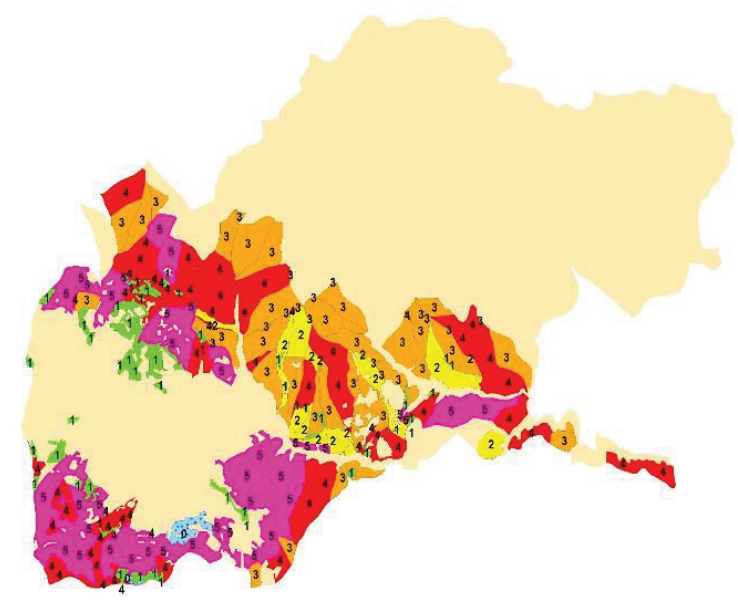

Strategy 2

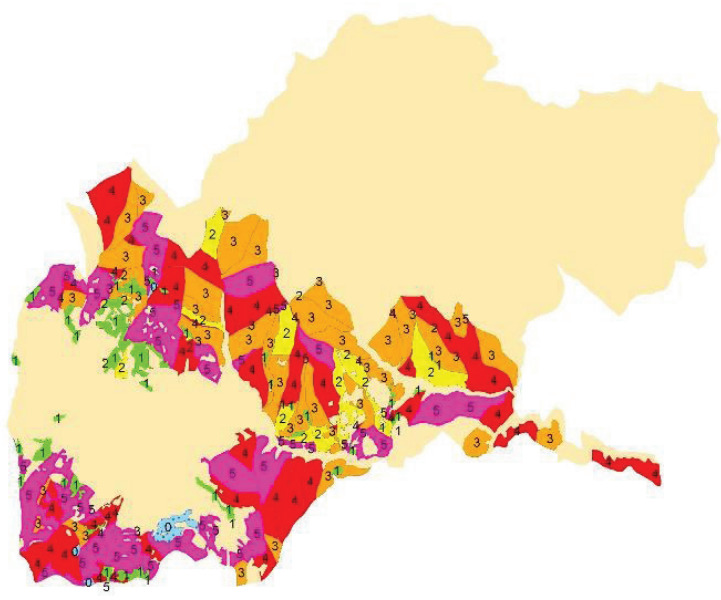

Strategy 3

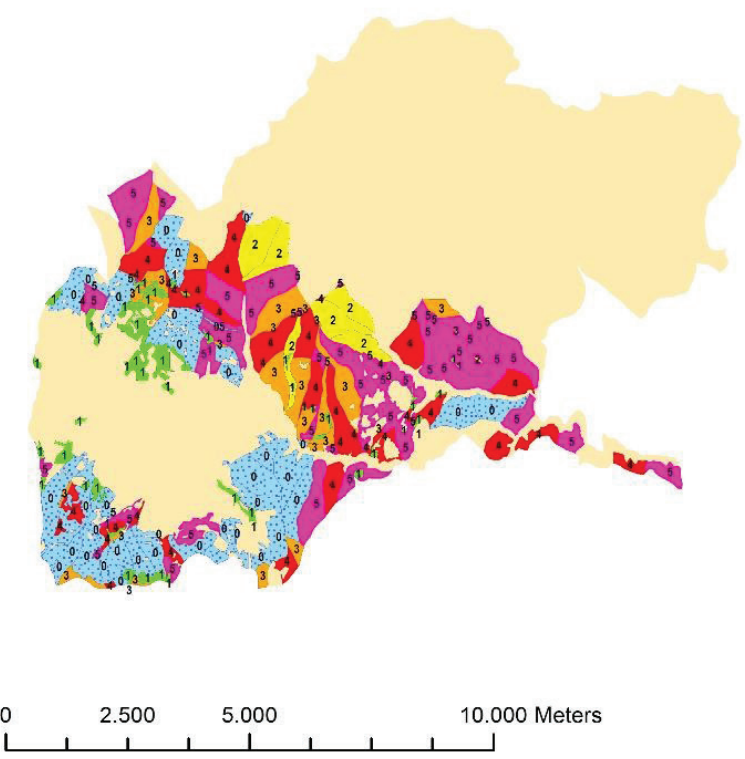

Strategy 4

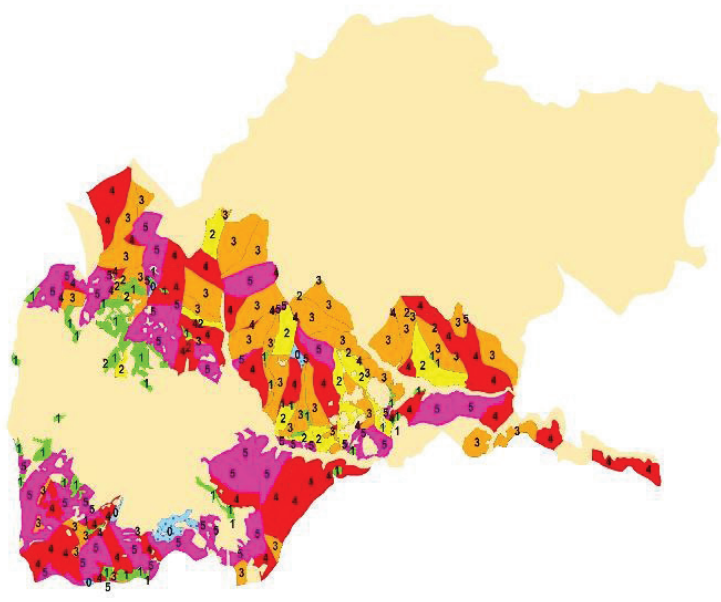

Strategy 1-2-3-4

Regeneration periods

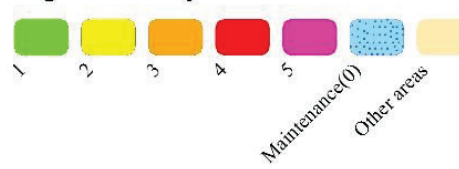

Figure 4. Periods of stands regeneration by the alternative strategies.

Períodos de regeneración de los asentamientos mediante estrategias alternativas. 
they are at the same age class, these stands will reach regeneration maturity at the same time. Nevertheless, since the regeneration on very large areas poses risk for the sustainability of forest, it was decided to model regeneration on $<1,000$ ha as a result of this, most of the wood production was achieved in the last three periods. Nevertheless, since the adjacent stands are of different sizes, the control of the areas to be regenerated (1,000 ha) may remain insufficient. For this reason, the number of adjacent stands was limited. At the same time, since inclusion of the spatial characteristics of the stands was not the main objective of the study, only a limited number of adjacent stands were involved in regeneration in the same period.

Within the 100-year scope of planning, the conversion of coppice into high forest is performed via natural regeneration, and wood production is optimized. For this reason, it is needed to utilize the planning horizon as both the conversion process and arranging process and to wait for the abundant-seed age of stands for selecting the stands for conversion into high forest. During the comments made in İğneada, Demirköy and Kurklareli on oaks in 2008 and 2009 , it was observed that oak individuals did not form seed. However, in 2010, it was observed that oak individuals started to form seeds (Makineci et al. 2008). Considering the disease factors in the stands, they must be regenerated by providing seed support earlier than the seeding age.

Spatial constraints for harvest scheduling commonly limit the size of harvest openings and restrict harvest activities on adjacent stands for periods (Crowe et al. 2003). Spatial constraints such as adjacency constraints complicate the problem of finding optimal solutions because decision variables must be integer in nature (McDill and Braze 2001). In applications, dealing with adjacency problems, Kašpar et al. (2016) discussed the effect of reducing the number of adjacency constraints by different methods. Nevertheless, in this paper, reducing the number of adjacency constraints did not change time required to solve the problem because of the small scheduling problem. This situation is especially true in the case of large problems with complex spatial structures. We have confirmed this hypothesis as well for the problem that was examined in this paper.

\section{CONCLUSIONS}

Forest harvest scheduling has a prime role for forest management planning in all forest structures. In this research we have shown how to formulate harvest-scheduling problems for deterministic solutions using mixed integer linear programing. We have also shown that scheduling problems can be solved optimally within the planning horizon. Harvest scheduling should ensure uninterrupted wood production and increased profit of forest investments in every period. A practical alternative to achieving these goals is to increase the size of harvesting areas. Modelling harvesting scheduling as a conversion into high forest problems presented a viable option for including adjacency constraint, approach ARM and in forest harvesting planning. Because of the particular constraints (adjacency) and variables involved in the ARM approach, it is recommended for forest planning problems. The mixed integer linear programming is widely suitable for harvest scheduling problems supplying different optimization methods. To get better solutions this methods is warranted, aiming at finding the best value for the obtained solutions.

\section{REFERENCES}

Başkent EZ, S Keleş. 2006. Developing alternative wood harvesting strategies with linear programming in preparing forest management plans. Turkish Journal of Agriculture and Forestry 30(1): 67-79.

Borges P, I Martins, E Bergseng, T Eid, T Gobakken. 2016. Effects of site productivity on forest harvest scheduling subject to green-up and maximum area restrictions. Scandinavian Journal of Forest Research 31: 507-516.

Crowe K, J Nelson, M Boyland. 2003. Solving the area-restricted harvest-scheduling model using the branch and bound algorithm. Canadian Journal of Forest Research 33: 18041814.

Eraslan İ. 1981. Aynı Yaşlı Ormanların Optimal Kuruluşlara Götürülmesinde Kullanılabilecek Artım Yüzdeleri Simulasyon Yöntemi. Journal of the Faculty of Forestry Istanbul University (JFFIU) No. 2110/289. 38 p.

Eraslan İ, BS Evcimen. 1967. Trakya'daki Meşe Ormanlarının Hacim ve Hasılatı Hakkında Tamamlayıcı Araştırmalar. Journal of the Faculty of Forestry Istanbul University (JFFIU) 17(1): 32-56

Ferreira L, MF Constantino, JG Borges, J Garcia-Gonzalo. 2015. Addressing Wildfire Risk in a Landscape-Level Scheduling Model: An Application in Portugal. Forest Science 61: 266277.

GDF (General Directorate of Forestry, TR). 2015. The statistics for 2015. Consulted 15 jan. 2018. Available in https://www. ogm.gov.tr/ekutuphane/Sayfalar/Istatistikler

Kangas J, A Kangas. 2005. Multiple criteria decision support in forest management - the approach, methods applied, and experiences gained. Forest Ecology and Management 207: 133-143.

Kašpar J, R Marušák, P Bettinger. 2016. Time Efficiency of Selected Types of Adjacency Constraints in Solving Unit Restriction Models. Forests 7: 102. DOI:10.3390/f7050102

Kaya A, P Bettinger, K Boston, R Akbulut, Z Ucar, J Siry, C Cieszewski. 2016. Optimisation in Forest Management. Current Forestry Reports 2(1): 1-17.

Keles S, HA Yolasigmaz, EZ Baskent. 2007. Long-term modelling and analyzing of some important forest ecosystem values with linear programming. Fresenius Environmental Bulletin 16(8): 963.

Könnyü N, SF Tóth. 2013. A cutting plane method for solving harvest scheduling models with area restrictions. European Journal of Operational Research 228(1): 236-248.

Makineci E, E Yılmaz, M Kumbaşli, O Sevgi, H Yılmaz, S Çalışkan, H Zengin. 2008. Kuzey Trakya Koruya Tahvil Meşe Ekosistemlerinde Sağlık Durumu, Biyokütle, Karbon Depolama ve Faounistik Özelliklerin Belirlenmesi. Ankara, Turkey. Tübitak-Tovag. 46 p. 
McDill ME, J Braze. 2001. Using the branch and bound algorithm to solve forest planning problems with adjacency constraints. Forest Science 47: 403-418.

Murray A, S Snyder. 2000. Spatial modeling in forest management and natural resource planning. Forest Science 46: 153-156.

Murray AT, M Goycoolea, A Weintraub. 2004. Incorporating average and maximum area restrictions in harvest scheduling models. Canadian Journal of Forest Research 34: 456-464.

Nakajima ET, H Kanomata, M Matsumoto. 2016. Visualization of optimized solution space using a simulation system for the development of local forest management planning. Annals of Forest Research 59: 117-128.

Nalle DJ, JL Arthur, CA Montgomery. 2005. Economic impacts of adjacency and green-up constraints on timber production at a landscape scale. Journal of Forest Economics 10: 189-205.

Nobre S, LO Eriksson, R Trubins. 2016. The Use of Decision Support Systems in Forest Management: Analysis of FORSYS Country Reports. Forests 7(3): 72.

Odabasi T. 1976. Turkiye'de baltalik ve korulu baltalik ormanlari ve bunlarin koruya donusturulmesi olanaklari uzerine, arastirmalar. Taillis et les taillis sous futaies de la Turquie et re- cherches sur les possibilites de leurs conversion en futaies.). Orman Fak. Yayin, Turkey. Istanbul University. 218 p.

Rönnqvist M. 2003. Optimization in forestry. Mathematical Programming 97: 267-284.

Taha HA. 2006. Operations Research: An Introduction. Eighth Edition. Upper Saddle River, USA. Prentice Hall. 813 p.

Vopenka P, J Kaspar, R Marusak. 2015. GIS tool for optimization of forest harvest scheduling. Computers and Electronics in Agriculture 113: 254-259.

Wei R, AT Murray. 2015. Spatial uncertainty in harvest scheduling. Annals of Operations Research 232(1): 275-289.

Weintraub A, C Romero. 2006. Operations research models and the management of agricultural and forestry resources: a review and comparison. Interfaces 36(5): 446-457.

Yoshimoto A, M Konoshima. 2016. Spatially constrained harvest scheduling for multiple harvests by exact formulation with common matrix algebra. Journal of Forest Research 21: 15-22.

Zengin H, Ü Asan, S Destan, ME Ünal, A Yeş1l, P Bettinger, AS Değermenci. 2015. Modelıng Harvest Schedulıng in Multifunctional Planning of Forests For Longterm Water Yield Optımızation. Natural Resource Modeling 28(1): 59-85. 